\title{
Structural Properties and Temperature Behaviour of Optical Absorption Edge in Polycrystalline $\mathrm{ZnO}: \mathrm{X}(\mathrm{Cu}, \mathrm{Ag})$ Films
}

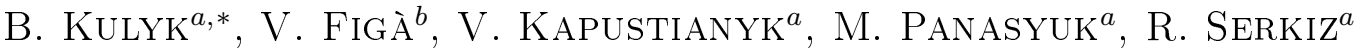 \\ AND P. DEMCHENKO ${ }^{c}$
}

${ }^{a}$ Scientific-Technical and Educational Center of Low Temperature Studies, Scientific and Educational Center

"FRACTAL", Department of Physics, Ivan Franko National University of Lviv

Dragomanova Str., 50, UA-79005 Lviv, Ukraine

${ }^{b}$ Department of Chemistry, University of Palermo, Viale delle Scienze - ed. 17, 90128 Palermo, Italy

${ }^{c}$ Department of Inorganic Chemistry, Ivan Franko National University of Lviv

Kyryla i Mefodiya Street, 6, UA-79005 Lviv, Ukraine

(Received April 30, 2012)

Silver- and copper-doped $\mathrm{ZnO}$ films were prepared by radio-frequency magnetron sputtering on glass substrates. The influence of dopants content on the structural, morphological properties as well as on evolution of the optical absorption edge was considered. It has been found that $\mathrm{Ag}$ - and $\mathrm{Cu}$-doped $\mathrm{ZnO}$ films are characterized by wurtzite crystalline structure with the preferred direction of crystalline orientation (002). The sizes of grains within the films were found to be dependent on the type of dopant. The temperature evolution of the optical absorption edge is described by the modified Urbach rule that reflects polycrystalline nature of the material. The corresponding parameters concerning electron- (exciton-) phonon interaction, phonon energies and temperature changes of the band-gap were determined and analysed.

DOI: 10.12693/APhysPolA.123.92

PACS: 68.37.Ps, 78.40.Fy, 68.55.ag

\section{Introduction}

$\mathrm{ZnO}$ is a very interesting material for many different applications in both microelectronic and optoelectronic devices. It is a wide bandgap oxide semiconductor with a direct energy gap of about $3.37 \mathrm{eV}$ and high exciton binding energy of $60 \mathrm{meV}$ at room temperature. Though, $\mathrm{ZnO}$ absorbs (UV) radiation due to band-to-band transition, it can be used as transparent conductive oxide thin film, mainly for applications such as solar cells, liquid crystal displays and heat mirrors [1-3]. Furthermore, $\mathrm{ZnO}$ is used in semiconducting multilayers, in gas sensors and optical position sensors, UV light-emitters, surface acoustic wave devices, piezoelectric transducers $[4,5]$. During the last years $\mathrm{ZnO}$ has emerged as one of the most promising materials due to its optical and electrical properties, high mechanical and chemical stability together with its abundance in nature and non-toxicity. In order to improve the properties of $\mathrm{ZnO}$ films, several techniques such as sputtering, thermal evaporation, metal-organic chemical vapour deposition, spray pyrolysis, pulsed laser and electrochemical depositions have been applied for their production. The radio-frequency (rf) magnetron sputtering technique is one of preferred among these techniques since it is versatile and permits to produce the high-quality films for different applications.

\footnotetext{
*corresponding author; e-mail: bohdan_kulyk@yahoo.com
}

The structural, physical and electrical properties of $\mathrm{ZnO}$ films were governed by deposition parameters [6], post-treatment [7-9] and doping material [10-16], such as $\mathrm{Al}, \mathrm{Ga}, \mathrm{Sc}, \mathrm{Y}, \mathrm{Mn}, \mathrm{Cu}, \mathrm{Ag}$, etc. In addition, it is known that the metals of group I $(\mathrm{Ag}, \mathrm{Cu})$ would be considered as the fast-diffusing impurities in the semiconductor compound [6]. The diffusion of copper or silver into $\mathrm{ZnO}$ can cause changes in the characteristics of its structure and, therefore, in the other physical properties.

The $\mathrm{Ag}$ and $\mathrm{Cu}$ dopants in $\mathrm{ZnO}$ may behave like many other monovalent dopant ions, which have the ability to occupy both the lattice and interstitial sites (i.e. amphoteric dopants), that would be expressed as [13]:

$$
\begin{aligned}
& 2 \mathrm{Ag} \stackrel{\mathrm{ZnO}}{\longrightarrow} \mathrm{Ag}_{\mathrm{Zn}}+\mathrm{Ag}_{\mathrm{i}}, \\
& 2 \mathrm{Cu} \stackrel{\mathrm{ZnO}}{\longrightarrow} \mathrm{Cu}_{\mathrm{Zn}}+\mathrm{Cu}_{\mathrm{i}} .
\end{aligned}
$$

The $\mathrm{Ag}$ and $\mathrm{Cu}$ centres in $\mathrm{ZnO}$ can occur in the following different charge states: $\mathrm{Ag}^{0}, \mathrm{Ag}^{+}, \mathrm{Ag}^{2+}$ and $\mathrm{Cu}^{0}$, $\mathrm{Cu}^{+}, \mathrm{Cu}^{2+}$, respectively. When $\mathrm{Ag}^{+}$or $\mathrm{Cu}^{+}$substitute $\mathrm{Zn}^{2+}$ they act as acceptor in $\mathrm{ZnO}$ matrix, while the interstitial $\mathrm{Ag}^{2+}$ or $\mathrm{Cu}^{2+}$ are donors. However, $\mathrm{Ag}^{0}$ and $\mathrm{Ag}^{2+}$ or $\mathrm{Cu}^{0}$ and $\mathrm{Cu}^{2+}$ ions can easily lose or gain electron resulting in the formation of $\mathrm{Ag}^{+}$or $\mathrm{Cu}^{+}$that implies appearance of more acceptor centres [12]. Beside these dopant centres the other defects such as $\mathrm{Zn}_{\mathrm{i}}, \mathrm{V}_{\mathrm{O}}$, $\mathrm{O}_{\mathrm{i}}, \mathrm{V}_{\mathrm{Zn}}$ can be present. They occur even in undoped $\mathrm{ZnO}$ [7]. The $\mathrm{Ag}$-, $\mathrm{Cu}$-doped $\mathrm{ZnO}$ films taken in various concentrations were already studied by photosensitivity, luminescent properties, electrical stability and have been 
used for different applications. Copper-doped $\mathrm{ZnO}$ is a good candidate in p-type $\mathrm{ZnO}$ [17] and sensors [18] as well as silver-doped $\mathrm{ZnO}$ are used in varistors [19], photocatalyst [20], etc. However, there are not many reports concerning the study of temperature behaviour of the optical absorption edge of such films. In this paper, therefore, we investigate the effect of dopants on structural, morphological features and temperature evolution of absorption edge in $\mathrm{ZnO}$ thin films.

\section{Experimental details}

The $\mathrm{ZnO}: \mathrm{Ag}$ and $\mathrm{ZnO}: \mathrm{Cu}$ thin films were deposited on glass substrates by means of rf-magnetron sputtering system from the targets of pressed $\mathrm{ZnO}$ powder $(99.99 \%)$ together with metallic $\mathrm{Ag}$ or oxide $\mathrm{CuO}$ (99.99\%) in argonoxygen atmosphere at the gas pressure of $10^{-3}$ Torr. The argon partial pressure $P_{\mathrm{Ar}}\left(\mathrm{Ar} /\left(\mathrm{Ar}+\mathrm{O}_{2}\right)\right)$ was $80 \%$. In order to minimize the thermal stresses the substrate temperature was fixed at $300{ }^{\circ} \mathrm{C}$. The target-to-substrate distance was $60 \mathrm{~mm}$ and rf-power $-100 \mathrm{~W}$.

The atomic amount of $\mathrm{Ag}$ and $\mathrm{Cu}$ dopants in $\mathrm{ZnO}$ films (taken from energy dispersive X-ray (EDX) analysis using a REMMA-102-02 scanning electron microscope, working at $20 \mathrm{kV}$ dc acceleration voltages in vacuum) was $1.6 \%, 5.9 \%$ and $0.5 \%, 1.5 \%, 3.3 \%, 5.0 \%$, respectively. The thickness of $\mathrm{ZnO}$ thin films was estimated by the deposition time and by Dektak surface stylus profiler (model: Veeco) and was found to be about $1200 \mathrm{~nm}$.

The X-ray diffraction (XRD) measurements were carried out using STOE STADI P diffractometer with linear position sensitive detector in transmission Bragg-Brentano geometry $\left(\mathrm{Cu} K_{\alpha_{1}}\right.$ radiation at $\lambda=$ $1.5406 \AA, \mathrm{Ge}(111)$ monochromator, detector scanning step: $0.480^{\circ} 2 \theta$, accumulation time: $320 \mathrm{~s}, 2 \theta$ angle resolution: $0.015^{\circ}, 2 \theta$ range: $23-115^{\circ}$ ). The atomic force microscopy (AFM) scans were performed in contact mode using a Solver P47-PRO scanning probe microscope (NT-MDT). Processing of images was done using the Image Analysis program (NT-MDT).

The temperature evolution of the optical absorption edge was measured using a setup based on SF-4A quartz monochromator in the range from 350 to $450 \mathrm{~nm}$.

\section{Results and discussion}

\subsection{XRD analysis}

The XRD spectra of $\mathrm{ZnO}$ and $\mathrm{ZnO}: \mathrm{Ag}$ thin films of wurtzite structure are shown in Fig. 1 (also Table I). As one can see, the doping of $\mathrm{ZnO}$ film by a few percents of silver does not affect the crystalline structure of the film considerably. From the XRD patterns and as it is evident from previous reports $[7,10,12,13,21-23]$, the silver-doped $\mathrm{ZnO}$ films have preferred orientation in the (002) direction. Besides, the additional low-intensity peaks corresponding to (100) and (101) directions in $\mathrm{ZnO}$ are observed. In the XRD spectra of $\mathrm{ZnO}$ film with higher amount of $\mathrm{Ag}$ ions (5.9 at.\%) at $2 \theta=38.12^{\circ}$ there appears a peak corresponding to the phase of silver. The relative intensity of (002)-peak in respect to the intensity of (101)-peak was found to be higher than those for the film with a lower $\mathrm{Ag}$ concentration (1.6 at.\%). Since $\mathrm{Ag}^{+}$ions have a larger radius $(0.122 \mathrm{~nm})$ than $\mathrm{Zn}^{2+}$ $(0.074 \mathrm{~nm})$ they either substitute ions of $\mathrm{Zn}^{2+}$ that leads to distortion of the unit cell or segregate at the grain boundaries of $\mathrm{ZnO}$ and hence induce considerable disorder and faster grow of $\mathrm{ZnO}$ grains $[13,23] . \mathrm{Ag}^{+}$would preferentially choose to sit in the vicinity of grain boundaries due to its large ionic radius. Thus, it is suggested that increase of the silver amount in $\mathrm{ZnO}$ film leads to its segregation at the grain boundaries and simultaneously decrease of the amount of substituted $\mathrm{Ag}^{+}$ions. Under such circumstances the crystalline quality of $\mathrm{ZnO}$ film appeared to be higher.

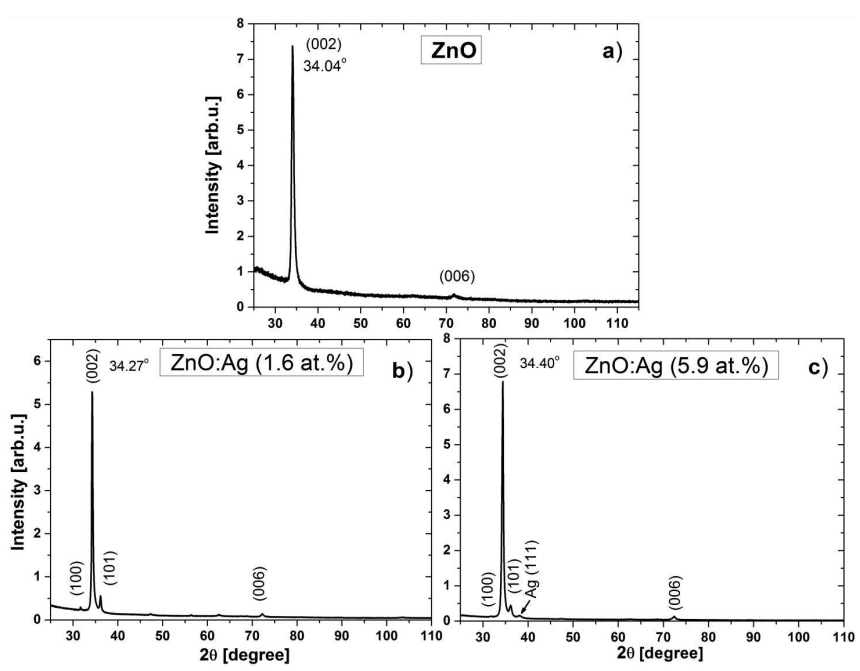

Fig. 1. XRD spectra of $\mathrm{ZnO}$ films: (a) $\mathrm{ZnO}$ undoped, (b) $\mathrm{ZnO}: \operatorname{Ag}(1.6$ at.\%), (c) $\mathrm{ZnO}: \operatorname{Ag}(5.9$ at.\%).

TABLE I

$d$-spacing of the (002) plane and FWHM of (002) peak of $\mathrm{Ag}$ and $\mathrm{Cu}$-doped $\mathrm{ZnO}$ films taken from XRD spectra.

\begin{tabular}{c|c|c}
\hline \hline Film & $d[\AA]$ & ${\text { FWHM }\left[{ }^{\circ}\right]}^{\circ}$ \\
\hline $\mathrm{ZnO}$ & 2.632 & 0.590 \\
$\mathrm{ZnO}: \mathrm{Ag}(1.6$ at.\%) & 2.615 & 0.302 \\
$\mathrm{ZnO}: \mathrm{Ag}(5.9$ at.\%) & 2.605 & 0.364 \\
$\mathrm{ZnO}: \mathrm{Cu}(0.5$ at.\%) & 2.631 & 0.587 \\
$\mathrm{ZnO}: \mathrm{Cu}(1.5$ at.\%) & 2.614 & 0.377 \\
$\mathrm{ZnO}: \mathrm{Cu}(3.3$ at.\%) & 2.610 & 0.380 \\
$\mathrm{ZnO}: \mathrm{Cu}(5.0$ at.\%) & 2.613 & 0.233
\end{tabular}

Figure 2 presents the XRD spectra of $\mathrm{ZnO}$ films doped by copper of various concentrations. It is important to note that $\mathrm{ZnO}: \mathrm{Cu}$ films possess a more pronounced preferred direction of crystalline orientation (002) with the increase of atomic amount of $\mathrm{Cu}$ from 0.5 to $5.0 \%$. This 
predicts that $\mathrm{Cu}$ ions occupy the lattice sites of $\mathrm{ZnO}[6,8$, $22,24-26]$. The radius of $\mathrm{Cu}^{2+}(0.072 \mathrm{~nm})$ is a little smaller, meanwhile, the radius of $\mathrm{Cu}^{+}$is larger than that of $\mathrm{Zn}^{2+}(0.074 \mathrm{~nm})$. The substitution of $\mathrm{Zn}^{2+}$ ions is advantageous for $\mathrm{Cu}^{2+}$ because of their close radii. When $\mathrm{Cu}^{2+}$ ions substitute $\mathrm{Zn}^{2+}$ ions, the lattice constant decreases [25]. Besides, due to their small radius the copper ions can be interstitial dopants or would create the metallic clusters. The exception is $\mathrm{ZnO}: \mathrm{Cu}(3.3$ at.\%) film in XRD spectra of which beside principal (002)-peak, a few other is noticeable including that one which corresponds to $\mathrm{Zn}$ phase. Such difference in structure of $\mathrm{ZnO}: \mathrm{Cu}(3.3$ at.\%) film could be caused by the fluctuations during film deposition.

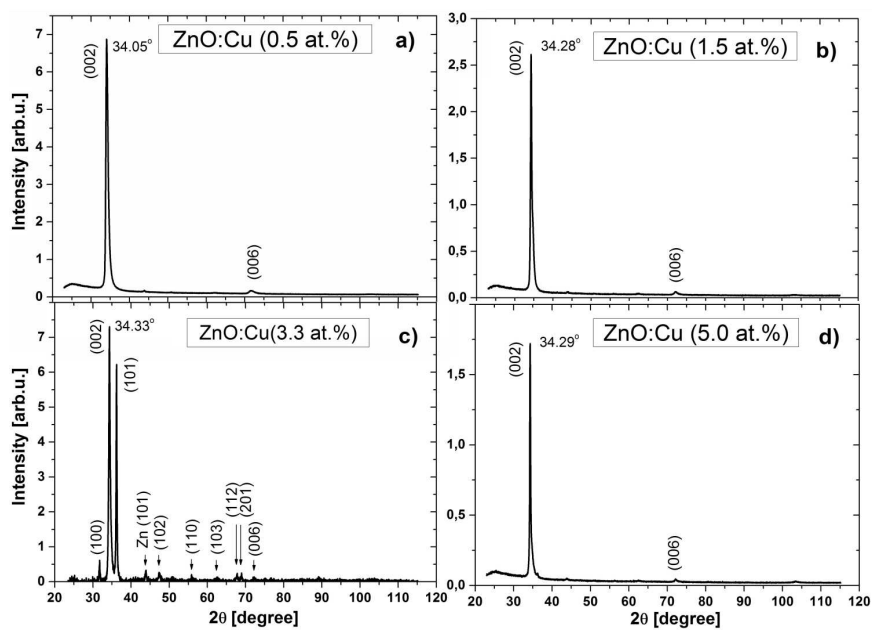

Fig. 2. XRD spectra of $\mathrm{ZnO}$ films: $\mathrm{ZnO}: \mathrm{Cu}(0.5$ at.\%), (b) $\mathrm{ZnO}: \mathrm{Cu}(1.5$ at.\%), (a) $\mathrm{ZnO}: \mathrm{Cu}(3.3$ at.\%), (d) $\mathrm{ZnO}: \mathrm{Cu}(5.0$ at.\%).

Moreover, with the increase of copper or silver dopant amount, in the XRD spectra the shift of (002)-peak into direction of higher values of $2 \theta$ takes place in the XRD spectra due to isomorphous substitution of $\mathrm{Zn}^{2+}$ ions by $\mathrm{Ag}^{+}$or $\mathrm{Cu}^{2+}$ ions. The parameters taken from these spectra are presented in Table I. With the increase of dopant $(\mathrm{Ag}, \mathrm{Cu})$ concentration the lattice $d$-spacing in doped $\mathrm{ZnO}$ films decreases. Meanwhile, the FWHM parameter for doped films is less than in undoped $\mathrm{ZnO}$ films.

\subsection{Microstructure and morphology analysis}

AFM micrograph analysis indicates the granular character of the deposited films. Figure 3 shows the AFM images of $\mathrm{ZnO}$ film and $\mathrm{ZnO}$ films doped with practically similar concentration of copper and silver dopant -1.5 at. $\%$ and 1.6 at.\%, respectively. The average grain size and the surface roughness obtained from those data (Table II) are connected with the amount of $\mathrm{Cu}$ or $\mathrm{Ag}$ dopants i.e. they decrease with increase of $\mathrm{Cu}$ concentration and increase with increase of $\mathrm{Ag}$ concentration. It is evident that the difference in the ionic radii of the dopants in respect of $\mathrm{Zn}^{2+}$ ion implies better $\mathrm{ZnO}$ grain growth during film deposition.

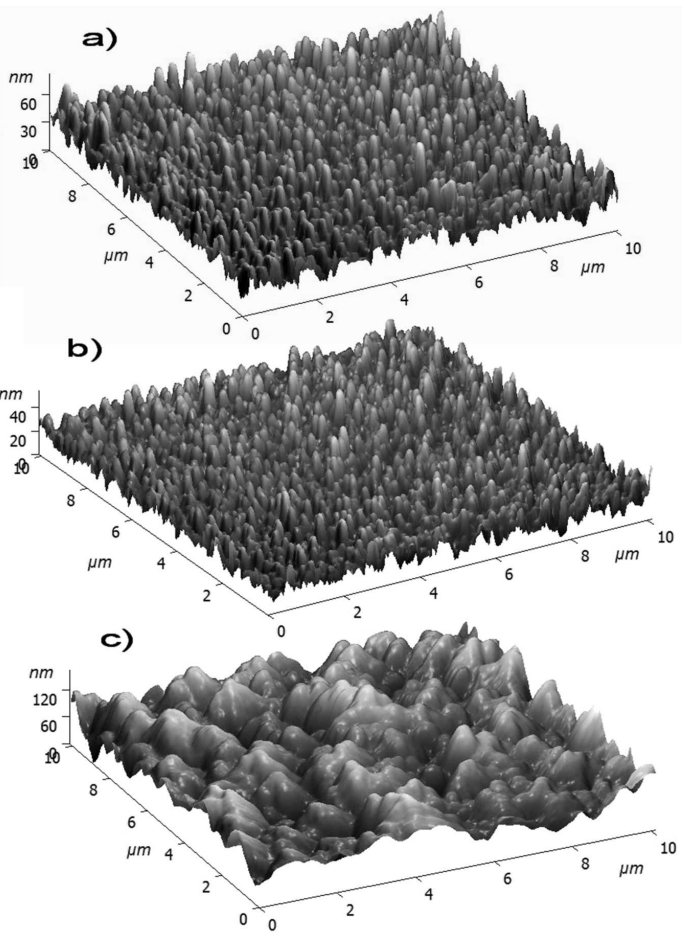

Fig. 3. AFM images of the films: (a) $\mathrm{ZnO}$ undoped; (b) $\mathrm{ZnO}: \mathrm{Cu}(1.5$ at.\%); (c) $\mathrm{ZnO}: \mathrm{Ag}(1.6$ at.\%).

TABLE II

Topological parameters of $\mathrm{ZnO}$ films, undoped and doped with $\mathrm{Cu}$ and $\mathrm{Ag}$.

\begin{tabular}{c|c|c}
\hline \hline Film & $\begin{array}{c}\text { Roughness } \\
R_{q}[\mathrm{~nm}]\end{array}$ & $\begin{array}{c}\text { Average height } \\
D[\mathrm{~nm}]\end{array}$ \\
\hline $\mathrm{ZnO}$ & 7.93 & 32.4 \\
$\mathrm{ZnO}: \mathrm{Cu}(1.5$ at.\%) & 6.22 & 23.4 \\
$\mathrm{ZnO}: \mathrm{Cu}(3.3$ at.\%) & 5.48 & 21.0 \\
$\mathrm{ZnO}: \mathrm{Cu}(5.0$ at.\%) & 4.90 & 16.6 \\
$\mathrm{ZnO}: \mathrm{Ag}(1.6$ at.\% $)$ & 24.0 & 83.5 \\
$\mathrm{ZnO}: \mathrm{Ag}(5.9$ at.\% $)$ & 27.0 & 120
\end{tabular}

\subsection{Temperature evolution of the absorption edge}

Zinc oxide is a wide bandgap semiconductor and therefore is characterized by wide transparency range in visible region. The investigations of the optical properties first of all were concentrated on the investigations of temperature behaviour of the absorption edge in silver and copper doped $\mathrm{ZnO}$ films. In Fig. 4 the absorption spectra of $\mathrm{ZnO}$ films undoped and doped with $\mathrm{Ag}$ and $\mathrm{Cu}$ are shown in the vicinity of optical absorption edge $(T=100 \mathrm{~K})$. As one can notice, absorption edge becomes more slanted and shifts toward the lower energies due to the influence of dopant. Besides, the $\mathrm{ZnO}$ films with highest dopant amount is characterised by the highest absorption in the transparency region of $\mathrm{ZnO}$ which can be attributed to influence of the metallic clusters the phases of which were observed in XRD spectra. 


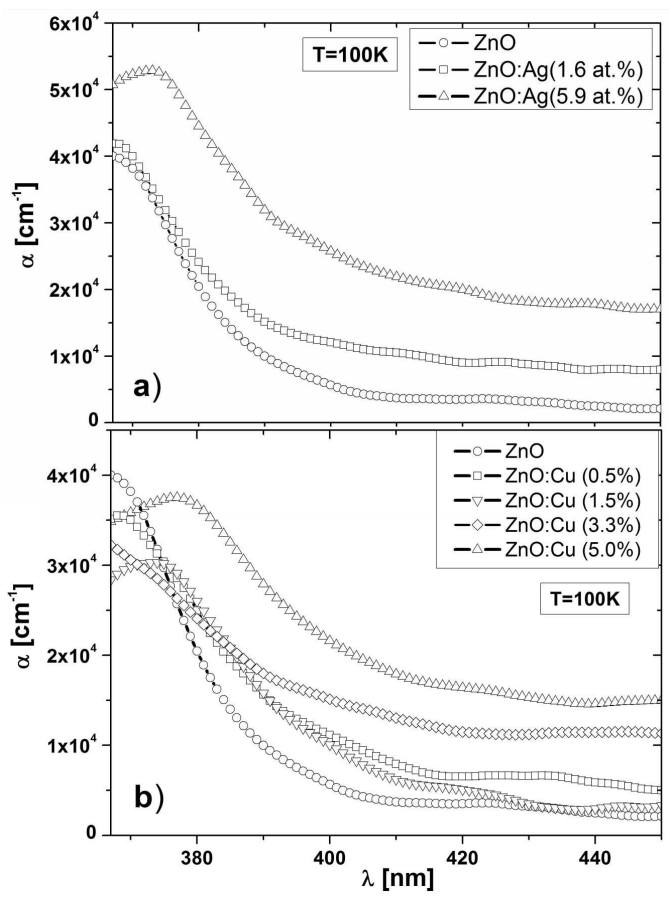

Fig. 4. Optical absorption edge of $\mathrm{ZnO}: \mathrm{Ag}$ (a) and $\mathrm{ZnO}: \mathrm{Cu}$ (b) films measured at $100 \mathrm{~K}$.

Temperature behaviour of the absorption edge of $\mathrm{ZnO}$ single crystal is described by empirical Urbach's rule. In this case the absorption coefficient can be given as [27, 28]:

$$
\alpha(\hbar \omega, T)=\alpha_{0} \exp \left(\frac{\sigma}{k_{\mathrm{B}} T}\left(\hbar \omega-E_{0}\right)\right),
$$

where $\alpha_{0}, E_{0}$ are Urbach's rule parameters which characterize a crystal, $k_{\mathrm{B}}$ is the Boltzmann constant, parameter $\sigma$ defines the slope of the spectral curves.

For all the films $(\mathrm{ZnO}, \mathrm{ZnO}: \mathrm{Ag}$ and $\mathrm{ZnO}: \mathrm{Cu})$ in the temperature range $80 \div 280 \mathrm{~K}$ the dependence $\ln (\alpha)=$ $f(E)$, presented in Fig. 5, has a linear character which confirms the exponential dependence of absorption coefficient on photon energy according to Eq. (3). The slope of these curves remains practically the same and we observe a parallel shift toward lower energy. This provides a basis for assuming that the temperature variation of absorption edge in the studied films is described by a modified Urbach rule [29, 30]:

$$
\alpha(\hbar \omega, T)=\alpha_{0} \exp \left(\frac{h \nu-E_{\mathrm{g}}(T)}{W}\right),
$$

where $W=W_{\mathrm{s}}+W_{\mathrm{d}}, W_{\mathrm{s}}$ and $W_{\mathrm{d}}=k_{\mathrm{B}} T / \sigma$ characterize static and dynamic disorder due to "frozen" and thermal phonons in the system, respectively. According to this rule, the slope of energy dependence of logarithm of the absorption coefficient in contrast to bulk materials does not change with temperature increase and parallel shift of these dependences into direction of lower energy takes place. Such a behaviour is usual for amorphous or polycrystalline materials [27].

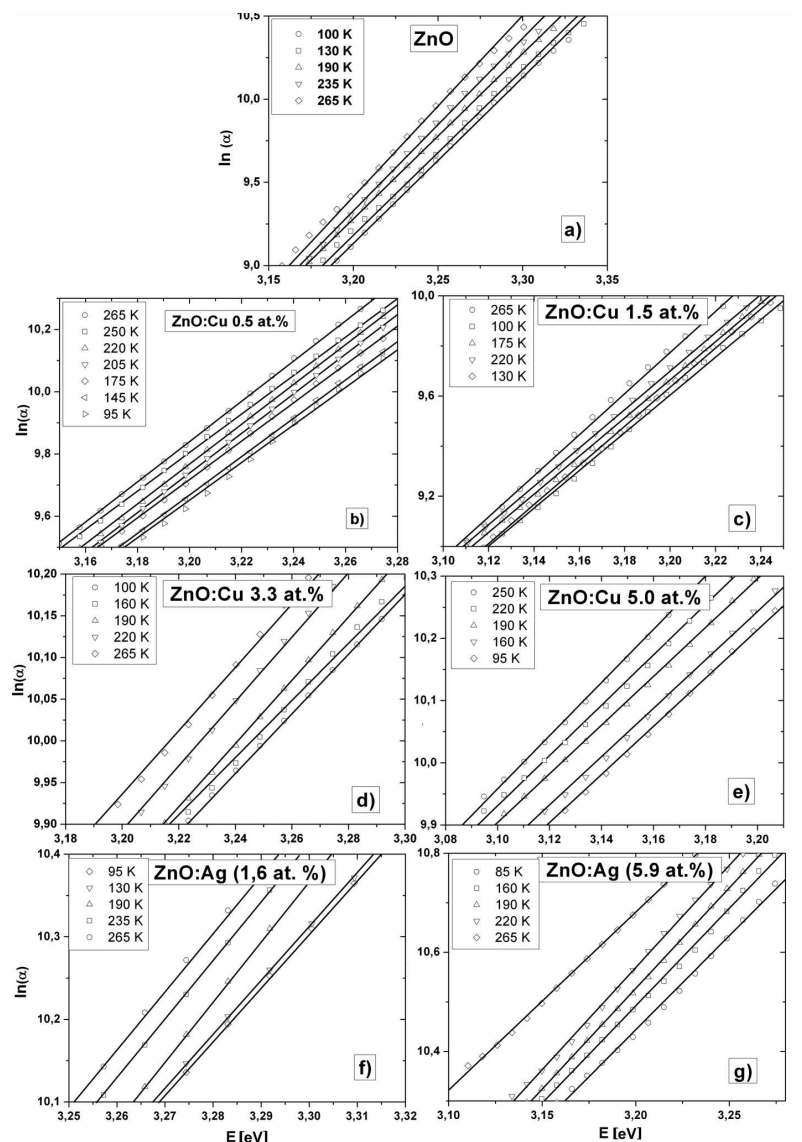

Fig. 5. Dependences $\ln (\alpha)=f(E)$ for the films: (a) $\mathrm{ZnO}$; (b) $\mathrm{ZnO}: \mathrm{Cu}(0.5$ at.\%); (c) $\mathrm{ZnO}: \mathrm{Cu}(1.5$ at.\%); (d) $\mathrm{ZnO}: \mathrm{Cu}(3.3$ at.\%); (e) $\mathrm{ZnO}: \mathrm{Cu}(5.0$ at.\%); (f) $\mathrm{ZnO}: \operatorname{Ag}(1.6$ at.\%); (g) $\mathrm{ZnO}: \operatorname{Ag}(5.9$ at.\%).

In the case when the thermal phonon mechanism predominates in broadening of the absorption edge, the temperature dependence of parameter $\sigma(T)$, describing the slope of the optical absorption edge is following [31]:

$$
\sigma(T)=\sigma_{0} \frac{2 k_{\mathrm{B}} T}{h \nu_{\mathrm{ph}}} \operatorname{th}\left(\frac{h \nu_{\mathrm{ph}}}{2 k_{\mathrm{B}} T}\right),
$$

where $\sigma_{0}$ is constant, which is inverse proportional to the electron- (exciton-) phonon interaction, $h \nu_{\mathrm{ph}}$ is the effective energy of phonons participating in absorption edge formation.

Temperature dependence $\sigma(T)$, defined from the slope of $\ln (\alpha)=f(E)$, is shown in Fig. 6. For all the samples, it has a linear character confirmed by their parallelism. Since the parameter $\sigma(T)$ is connected with the slope of absorption edge one can notice that the absorption edge is most bluff in the undoped $\mathrm{ZnO}$ film. The dependence of $\sigma(T)$ on the dopant concentration is not monotonic. At the same time this parameter increases at heating for all studied films.

To determine the phonon energies $h \nu_{\mathrm{ph}}$ and $\sigma_{0}$ constants for the investigated films, it is necessary to expand $\operatorname{th}\left(h \nu_{\mathrm{ph}} / 2 k_{\mathrm{B}} T\right)$ in series and take into account first two 


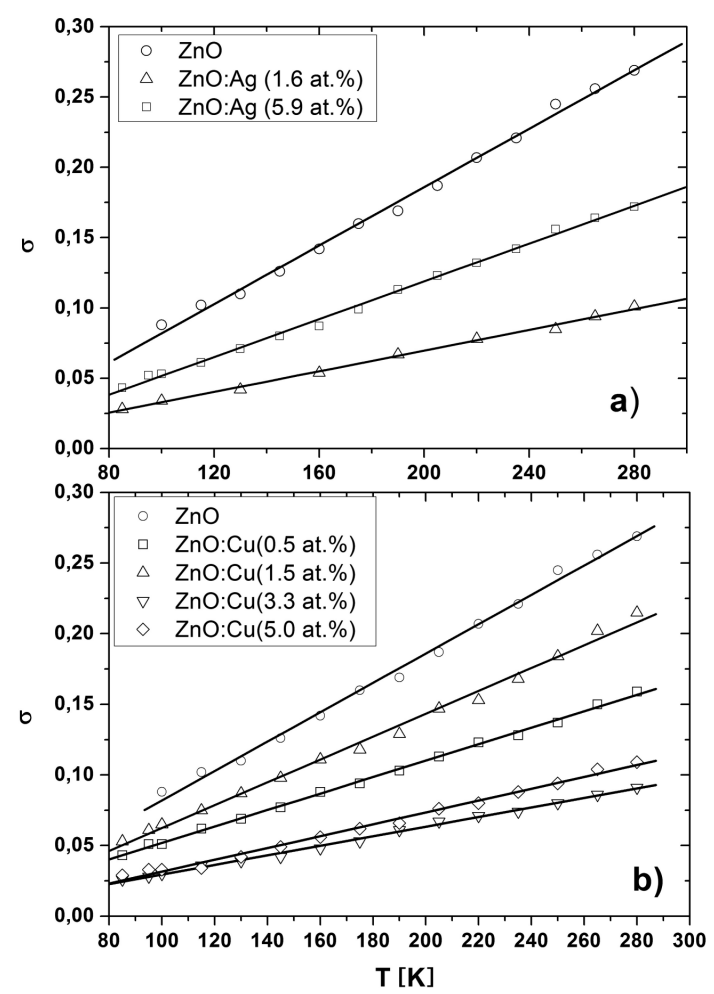

Fig. 6. Temperature dependence of $\sigma(T)$ parameter for the films: (a) $\mathrm{ZnO}: \mathrm{Ag}$ and (b) $\mathrm{ZnO}: \mathrm{Cu}$.

terms [32]:

$$
\sigma(T)=\sigma_{0}\left[1-\frac{1}{3}\left(\frac{h \nu_{\mathrm{ph}}}{2 k_{\mathrm{B}} T}\right)^{2}\right] .
$$

Drawing the dependence of $\sigma(T)$ from $1 / T^{2}$ and using a linear extrapolation from the side of higher temperatures, the values of $\nu_{\mathrm{ph}}$ and $\sigma_{0}$ were found for Ag- and $\mathrm{Cu}$-doped $\mathrm{ZnO}$ films (Table III). Constant $\sigma_{0}$ is inversely proportional to the strength of electron(exciton-) phonon interaction $g$ :

$$
\sigma_{0}=\frac{3}{2} \frac{1}{g}
$$

TABLE III

Obtained values of $\nu_{\mathrm{ph}}$ and $\sigma_{0}$ for the $\mathrm{ZnO}, \mathrm{ZnO}: \mathrm{Ag}$ and $\mathrm{ZnO}: \mathrm{Cu}$ films.

\begin{tabular}{c|c|c}
\hline \hline Film & $\sigma_{0}$ & $\nu_{\mathrm{ph}}\left[\mathrm{cm}^{-1}\right]([\mathrm{meV}])$ \\
\hline $\mathrm{ZnO}$ & 0.363 & $347(43.0)$ \\
$\mathrm{ZnO}: \mathrm{Ag}(1.6$ at.\%) & 0.235 & $349(43.3)$ \\
$\mathrm{ZnO}: \mathrm{Ag}(5.9$ at.\%) & 0.164 & $418(51.9)$ \\
$\mathrm{ZnO}: \mathrm{Cu}(0.5$ at. \%) & 0.234 & $383(47.5)$ \\
$\mathrm{ZnO}: \mathrm{Cu}(1.5$ at.\%) & 0.328 & $397(49.2)$ \\
$\mathrm{ZnO}: \mathrm{Cu}(3.3$ at. $\%)$ & 0.132 & $375(46.5)$ \\
$\mathrm{ZnO}: \mathrm{Cu}(5.0$ at.\%) & 0.161 & $384(47.6)$
\end{tabular}

Therefore, in $\mathrm{ZnO}$ films the strength of electron(exciton-) phonon interaction grows with the dopant (Ag or $\mathrm{Cu}$ ) amount increasing. The calculated effective energies of phonons can be referred to the transverse optical phonons. Their wave number in the bulk $\mathrm{ZnO}$ is $380 \mathrm{~cm}^{-1}$ [33].

However, the direct determination of band-gap energy $E_{\mathrm{g}}$ is complicated when the Urbach broadening of absorption edge takes place. In this case the isoabsorption dependence $E^{\prime}(T)$ would reflect the temperature behaviour of $E_{\mathrm{g}}$ parameter. The values of $E^{\prime}$ correspond to a certain fixed absorption $\alpha=$ const (usually $0.3<\alpha d<3$, where $d$ is the thickness of a sample). In Fig. 7 the "isoabsorption" temperature dependence of energy $E^{\prime}\left(\alpha=2 \times 10^{4} \mathrm{~cm}^{-1}\right)$ is shown for the films doped with $\mathrm{Ag}$ and $\mathrm{Cu}$. As it is clearly seen, the energy $E^{\prime}$ decreases at heating. Therefore, one can conclude that the bandgap energy $E_{\mathrm{g}}$ also decreases with temperature increase and the situation looks very similar for all the doped films.

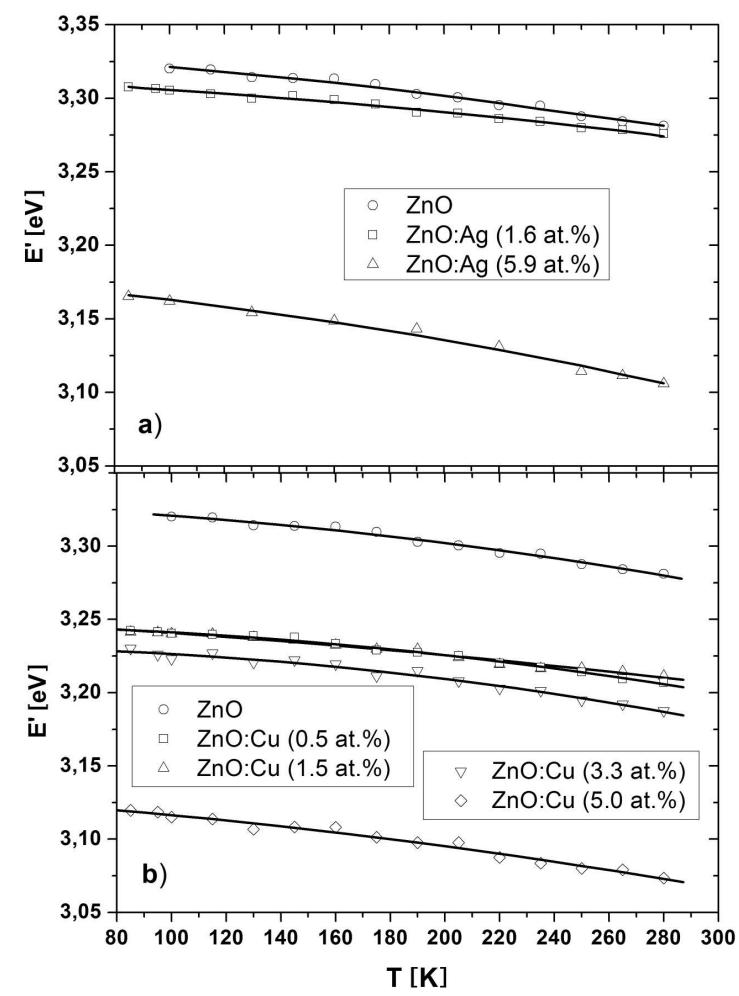

Fig. 7. Temperature dependence of $E^{\prime}(T)$ in $\mathrm{ZnO}: \mathrm{Ag}$ (a) and $\mathrm{ZnO}: \mathrm{Cu}$ (b) films.

Such temperature behaviour of $E^{\prime}$ is typical for crystalline materials. This confirms that the mechanisms of shifting and broadening of the optical absorption edge are similar for crystalline as well as for the polycrystalline and glassy materials and thermal phonons play a considerable role in these mechanisms. The fulfilment of the modified Urbach rule testifies that the investigated Agand $\mathrm{Cu}$-doped $\mathrm{ZnO}$ films are polycrystalline with quite small sizes of the crystallites. This conclusion correlates fairly well with the data of AFM analysis. 


\section{Conclusions}

The Ag- and $\mathrm{Cu}$-doped $\mathrm{ZnO}$ films prepared by rf-magnetron sputtering on glass substrates are characterized by a wurtzite structure with the $c$-axis perpendicular to the film surface. The mechanisms of $\mathrm{Ag}$ and $\mathrm{Cu}$ incorporation into $\mathrm{ZnO}$ structure were discussed and the shift of (002)-peak of wurtzite $\mathrm{ZnO}$ into direction of higher values of $2 \theta$ was found to be connected with the isomorphous substitution of $\mathrm{Zn}^{2+}$ ions by $\mathrm{Ag}^{+}$or $\mathrm{Cu}^{2+}$ ions. The morphological parameters taken from AFM investigations indicate that the presence of $\mathrm{Ag}$ dopant in $\mathrm{ZnO}$ involves a larger grain growth together with increasing roughness, whereas the presence of $\mathrm{Cu}$ dopant decreases a little the grain sizes. The temperature behaviour of the optical absorption edge in $\mathrm{ZnO}: \mathrm{Ag}$ and $\mathrm{ZnO}: \mathrm{Cu}$ films was described by a modified Urbach rule. The strength of electron- (exciton-) phonon interaction together with the energy of phonons was found to grow with a dopant (Ag or $\mathrm{Cu}$ ) amount increasing in $\mathrm{ZnO}$ films. The doping of $\mathrm{ZnO}$ with copper or silver permits the purposeful modification of its optical parameters, for example, energy position and shape of optical absorption edge.

\section{References}

[1] B.J. Lokhande, M.D. Uplane, Appl. Surf. Sci. 167, $243(2000)$

[2] R. Triboulet, J. Perrière, Prog. Cryst. Growth Charact. Mater. 47, 65 (2003)

[3] E. Fortunato, P. Barquinha, A. Pimentel, L. Pereira, A. Gonçalves, A. Marques, R. Martins, L. Pereira, Appl. Phys. Lett. 85, 2541 (2004)

[4] D. Brida, E. Fortunato, I. Ferreira, H. Aguas, R. Martins, J. Non-Cryst. Solids 299-302, 1272 (2002)

[5] Ü. Özgür, Ya.I. Alivov, C. Liu, A. Teke, M.A. Reshchikov, S. Doğan, V. Avrutin, S.-J. Cho, H. Morkoç, J. Appl. Phys. 98, 1 (2005).

[6] M. Öztas, M. Bedir, Thin Solid Films 516, 1703 (2008)

[7] L. Duan, W. Gao, R. Chen, Z. Fu, Solid State Commun. 145, 479 (2008)

[8] D. Chakraborti, G.R. Trichy, J.T. Prater, J. Narayan, J. Phys. D, Appl. Phys. 40, 7606 (2007).

[9] S.W. Xue, X.T. Zu, W.L. Zhou, H.X. Deng, X. Xiang, L. Zhang, H. Deng, J. Alloys Comp. 448, 21 (2008).

[10] S.H. Jeong, B.N. Park, S.B. Lee, J.-H. Boo, Surf. Coat. Technol. 193, 340 (2005).

[11] T. Kryshtab, V.S. Khomchenko, V.B. Khachatryan, N.N. Roshchina, J.A. Andraca-Adame, O.S. Lytvyn, V.I. Kushnirenko, J. Mater. Sci. Mater. Electron. 18, 1115 (2007)

[12] R. Deng, Y. Zou, H. Tang, Physica B 403, 2004 (2008)
[13] S.T. Kuo, W.H. Tuan, J. Shieh, S.F. Wang, J. Europ. Ceram. Soc. 27, 4521 (2007)

[14] Y. Zhang, L. Wu, H. Li, J. Xu, L. Han, B. Wang, Z. Tuo, E. Xie, J. Alloys Comp. 473, 319 (2009)

[15] P. Singh, A. Kaushal, D. Kaur, J. Alloys Comp. 471, $11(2009)$

[16] T. Ratana, P. Amornpitoksuk, T. Ratana, S. Suwanboon, J. Alloys Comp. 470, 408 (2009).

[17] D.B. Buchholz, R.P.H. Chang, J.H. Song, J.B. Ketterson, Appl. Phys. Lett. 87, 082504 (2005)

[18] H. Gong, J.Q. Hu, J.H. Wang, C.H. Ong, F.R. Zhu, Sensors Actuators B Chem. 115, 247 (2006)

[19] J. Fan, R. Freer, J. Appl. Phys. 77, 4795 (1995).

[20] C.A.K. Gouvea, F. Wypych, S.G. Moraes, N. Duran, P. Peralta-Zamora, Chemosphere 40, 427 (2000)

[21] S.H. Jeong, D.G. Yoo, D.Y. Kim, N.E. Lee, J.H. Boo, Thin Solid Films 516, 6598 (2008)

[22] V.S. Khomchenko, T.G. Kryshtab, A.K. Savin, L.V. Zavyalova, N.N. Roshchina, V.E. Rodionov, O.S. Lytvyn, V.I. Kushnirenko, V.B. Khachatryan, J.A. Andraca-Adame, Superlatt. Microstruct. 42, 94 (2007)

[23] Q. Wan, Z. Xiong, J. Dai, J. Rao, F. Jiang, Opt. Mater. 30, 817 (2008)

[24] X.B. Wang, D.M. Li, F. Zeng, F. Pan, J. Phys. D, Appl. Phys. 38, 4104 (2005)

[25] X. Peng, J. Xu, H. Zang, B. Wang, Z. Wang, J. Lumin. 128, 297 (2008)

[26] A. Tiwari, M. Snure, D. Kumar, J.T. Abiade, Appl. Phys. Lett. 92, 062509 (2008)

[27] B.I. Turko, V.B. Kapustianyk, V.P. Rudyk, G.A. Lubochkova, B.A. Simkiv, J. Appl. Spectrosc. 73, 222 (2006)

[28] S. Ilican, Y. Caglar, M. Caglar, J. Optoelectron. Adv. Mater. 10, 2578 (2008).

[29] J. Tauc, Mater. Res. Bull. 5, 721 (1970)

[30] N.E. Mott, E.A. Davis, Electronic Processes in Non-Crystalline Materials, Oxford University Press, London 1982.

[31] I.P. Kuz'mina, A.N. Lobachev, N.S. Triodina, A Study of Crzstal Synthesis in Hydrothermal Conditions, Ed. A.N. Lobachev, Nauka, Moscow, 1970, p. 29, (in Russian).

[32] S. Pačesova, B. Bržezina, L. Jastrabik, Phys. Status Solidi B 116, 545 (1985)

[33] B.K. Meyer, H. Alves, D.M. Hofmann, W. Kriegseis, D. Forster, F. Bertram, J. Christen, A. Hoffmann, M. Strabburg, M. Dworzak, U. Haboeck, A.V. Rodina, Phys. Status Solidi B 241, 231 (2004) 